Biol. Stud. 2013: 7(2); 107-118 • DOI: https://doi.org/10.30970/sbi.0702.286

www.http://publications.Inu.edu.ua/journals/index.php/biology

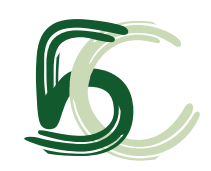

UDC 582.241: 581.526.42: $712.23(234.372 .3)$

\title{
MYXOMYCETES IN THE VIRGIN BEECH AND OLD-AGED SPRUCE FORESTS OF NATIONAL NATURE PARK "BEWITCHED LAND" (UKRAINIAN CARPATHIANS)
}

\author{
I. O. Dudka', T. I. Kryvomaz ${ }^{2}$ \\ ${ }^{1}$ M.G. Kholodny Institute of Botany, NAS of Ukraine, 2, Tereshchenkivska St., Kyiv 01601, Ukraine \\ e-mail: i_dudka@mail.ru \\ ${ }^{2}$ Kyiv National Construction and Architecture University, 31, Povitroflotskyi Ave., Kyiv 03680, Ukraine
}

Mycological observations in virgin beech and old-aged spruce forests of National Nature Park (NNP) "Bewitched Land" carried out in July 2011 allowed to reveal 20 myxomycete species. Ceratiomyxa fruticulosa belongs to subclass Ceratiomyxomycetidae, other 19 species are representatives of subclass Myxogastromycetidae, assigned to four orders: Trichiales (8 species), Physarales (5), Liceales and Stemonitales (on 3 species each). The highest frequency of occurrence was noted for Ceratiomyxa fruticulosa, Arcyria cinerea and Lycogala epidendrum. Dictydiaethalium plumbeum was determined as the species with rather limited distribution in Ukraine and the Ukrainian Carpathians, especially. Investigation of myxomycete substrate preferences showed that the most important woody species that supported development of the majority of slime molds in NNP "Bewitched Land" were spruce (Picea abies) and beech (Fagus sylvatica). Unlike the Carpathian biosphere reserve and NNP "Skolivski Beskydy" where myxomycetes predominantly used beech wood as a substrate myxomycete biota of "Bewitched Land" showed reverse type of substrate association preferring the wood of coniferous tree - spruce.

Keywords: National Nature Park "Bewitched Land", Myxomycetes, slime molds, virgin and old-aged forests, taxonomic diversity, substrate preferences.

\section{INTRODUCTION}

The dead wood - old stumps, trees destroyed by insects and damaged by various fungal and bacterial diseases but remain standing, fallen trunks, branches and twigs forms one of the richest microbiotopes for biological diversity in forest ecosystems. The dead wood together with associated species diversity plays the key role in supporting of forest productivity and stable development and in maintenance of its ecological balance. This microbiotope is especially important for the organisms which are tightly connected trophically and/or topically with wood substrates: insects, fungi, lichens, mosses etc.

In spite of the tremendous meaning of the dead wood its volume in economical forests is extremely low. The dead wood in managed forests of Europe fluctuated from $0.6 \mathrm{~m}^{3} / \mathrm{ha}$ in Austria to $12 \mathrm{~m}^{3} / \mathrm{ha}$ in Switzerland [37]. Only protected virgin or old-aged natural forests guarantee securing of the dead wood volumes necessary for support of 
biological diversity in forest ecosystems at the high level. In the Carpathians there are numerous protected areas which embrace the virgin beech, spruce and fir forests. The volumes of dead wood in reserves and nature parks with the virgin beech forests significantly increase in comparison with the managed ones. For example, it is known that in the virgin beech forests of the national park Semenik-Cheile-Karasului (Romania) accumulated mass of the dead wood varies in the ranges $78-121 \mathrm{~m}^{3} / \mathrm{ha}$. In another European virgin beech forest Haveshova (nature park Poloniny, Slovakia) upon the average $121 \mathrm{~m}^{3} / \mathrm{ha}$ of dead wood remains are collected. It is considered that the highest volumes of the dead wood for Carpathians are concentrated in the Uholka virgin beech forest (Carpathian biosphere reserve, Ukraine): here the content of woody remains composes $200(-300) \mathrm{m}^{3} /$ ha [19].

This important component of reserve ecosystems provides numerous forest inhabitants with food substances and specific biotopes, creating the favorable conditions for high and stable species diversity. First of all, it concerns so called xylobiont organisms whose development and further existence are impossible without woody substrates. The representatives of xylobiont ecological group are wide-spread among the fungi and fungi-like organisms, in particular myxomycetes. According to classification of myxomycetous ecological groups based on the substrate types slime molds associated with the dead wood are treated as xylophilous ones [7]. Xylophilous slime molds form the most numerous group among phytophilous myxomycetes: the third part of its known species (more than 300 ones) are recorded on the dead wood [33]. In Ukraine 168 species belong to xylophiles, making up $60.4 \%$ of the total number of myxomycetes recorded in our country till now [7]. Another ecological group - corticuloid - includes myxomycetes connected with tree bark. A part of them adopted to the dead tree bark may be considered as a supplement to the list of myxomycetous species associated with woody forest remains.

Taking into account substrate preferences of myxomycetes with regard to the dead wood together with the predominance of this substrate in virgin and old-aged forests, the first mycological observations on the species diversity of myxomycetes were held in 2006 at the territory of the above-mentioned Uholka virgin beech forest [21]. As an object for the following studies of species diversity and substrate preferences of myxomycetes virgin beech and old-aged spruce forests in NNP "Bewitched Land" were chosen. NNP was founded by the Decree of President of Ukraine №343 at 21.06.2009 at the territory of Irshavski district (Zakarpatska oblast). Park with an area of 6101 ha is situated on the south-western slopes of mountain massif Great Valley, central part of Vyhorlat-Gutyn volcanic ridge. In correspondence with the geobotanical division park territory is included in Verkhovyno-Beskydski district of oak, beech, spruce and fir forests. Fagus sylvatica L. occupies the largest area in the park and forms monodominant climax beech forests mainly [14]. Five forest associations of "Bewitched Land" are included in the Green Book of Ukraine. Two of them - Fageta sylvaticae with predominance of Lunaria rediviva $\mathrm{L}$. in grassy layer and Fageta sylvaticae with predominance of Allium ursinum L. in grassy layer - belong to the highest conservation category (1) and are characterized with the high synphytosozologic index: 11.5-12.6 for the first and 11.4-13.2 for the second one [6]. Several small plots of beech forests identified as virgin ones are preserved at the park territory [14]. One of such plot situated in the forest parcel Kamianka (Ilnytske forestry of NNP, near the village of Osiy) was explored for establishment of myxomycete species diversity and substrate preferences in July 2011. Except the Kamianka virgin beech forest collections of myxomycetes on the territory of "Bewitched Land" were simultaneously held in the old-aged spruce (Picea abies (L.) Karst.) forest near the swamp "Black Bog"

ISSN 1996-4536 • Біологічні Студії / Studia Biologica • 2013 • Том 7/№2 • C. 107-118 
(Pidgirnianske forestry of NNP, village of Pidgirne) and in many-aged beech forest with planted spruce in the geological reserve "Bewitched Valley".

\section{MATERIALS AND METHODS}

As a result of mycological inspections of the above-mentioned territories of NNP "Bewitched Land", organized in July 201149 specimens of myxomycetes were collected on the various plant substrates. The collection of myxomycete specimens was fulfilled during radial routes on the park territory using generally adopted methods. Records of myxomycetes were realized by inspection of a set of plant substrates (leaf litter, fallen tree trunks, old stumps, fallen branches, dead bark, dried and living grasses etc.) with the 10-multiple magnifier. The found specimen along with the part of substrate was cut by knife and carefully transferred to plastic box $(27 \times 17 \mathrm{~cm})$ divided inside on separate cells $(4 \times 17 \mathrm{~cm})$. A thin layer of cork material was placed at the box bottom to fix the collected specimens with metal pins in order to avoid myxomycete sporophores destruction. In laboratory the specimens were taken out the plastic box and dried at room temperature. After that for a long storage in herbarium every myxomycete specimen was transferred to the separate match box on the drop of liquid glue at the bottom to keep it motionlessly. Installed in such way specimens are well preserved and are fit to identification for a long time.

Light microscope GS M 27257 (10×, 20×, 40×, 90× lenses) and stereomicroscope Olympus VT-II 205816 (oculars 1×, 2x, 10x) with calibrated scale were used for the studies of myxomycete micromorphological characteristics taken into consideration for their identification. The special manuals devoted to slime molds from the orders and families of Myxomycetes serve as fundamental works for the establishment of taxonomic position of the collected specimens [15, 22, 30, 31, 33-35].

Latin names of Myxomycetes given in the paper are based on the nomenclatural catalogue "Novenmyx. A Nomenclatural Taxabase of Myxomycetes" [29]. "Vascular Plants of Ukraine. A Nomenclatural Checklist" is used as a reference book for Latin names of vascular plants [32]. Abbreviations of the authors' names of myxomycete species correspond to the recommended standard forms for authors of scientific names of fungi [23].

\section{RESULTS AND DISCUSSION}

Collections of myxomycetes in the above enumerated localities of NNP "Bewitched Land" together with the following identification of collected specimens resulted in 20 species of myxomycetes. Their species diversity is given in Table where myxomycete species recorded in NNP "Bewitched Land" are marked with asterisks. In accordance with the modern classification [24] all species from "Bewitched Land" belong to class Myxomycetes (Division Myxomycota). Representatives of subclass Myxogastromycetidae (19) dominate in taxonomic structure of slime molds found in the virgin beech and old-aged spruce forests of investigated reserved territory. Only one species (Ceratiomyxa fruticulosa) belongs to subclass Ceratiomyxomycetidae. Myxogastromycetids are assigned to four orders: Trichiales (8 species), Physarales (5), Liceales and Stemonitales (on 3 species each). Among the families of myxomycetes revealed in NNP "Bewitched Land" Trichiaceae with 8 species was prevalent. The remaining 11 species from Physarales, Liceales and Stemonitales were arranged in the families: Physaraceae (5), Reticulariaceae (3) and Stemonitidaceae (3) correspondingly. The distribution of recorded myxomycetes between the genera was following: Arcyria Wigg (Trichiaceae) and Physarum Pers. (Physaraceae) presented in "Bewitched Land" by 4 species each 
were the richest ones according to species composition in comparison with other 8 genera. Hemitrichia Rostaf., Trichia Haller (Trichiaceae) and Stemonitis Roth (Stemonitidaceae) embrace two species each. Only one species of every from the other genera Dictydiaethalium Rostaf., Lycogala Adans., Tubifera Gmel. (Reticulariaceae), Fuligo Haller (Physaraceae) and Comatricha Preuss (Stemonitidaceae) was found in NNP "Bewitched Land" during the expedition in July 2011.

Among the species of slime molds collected in the virgin beech and the old-aged spruce forests of NNP "Bewitched Land" rather limited number may be appreciated as a wide-spread one. The highest frequency of occurrence was noted for Ceratiomyxa fruticuIosa (Fig. 1), Arcyria cinerea (Fig. 2) and Lycogala epidendrum (Fig. 3) the numerous specimens of which were collected in the forest parcel Kamianka (the virgin beech forest along the river Syniavka), "Bewitched Valley" (the old-aged beech forest) and near the swamp "Black Bog" (the old-aged spruce forest). In two ("Bewitched Valley" and "Black Bog") from above-named three locations Arcyria denudata, Trichia affinis and Tubifera ferruginosa (Fig. 4) were recorded. Rather wide-spread slime molds Hemitrichia calyculata (Fig. 5) and Trichia decipiens (Fig. 6) were found only once: the first in the beech forest of parcel Kamianka, the second in the spruce forest near swamp "Black Bog". Physarum album (Fig. 7, 8) is a single species observed in "Bewitched Valley", forest parcel Kamianka and in the overgrowth of Alnus incana (L.) Moench in the village Innytsia. It should be mentioned another myxomycetes whose specimens were found in this anthropogenically modified location - the meadow with old apple garden and the overgrowth of A. incana on the bank of stream Bagynski in tne village Ilnytsia. In this location along with common species of slime molds Fuligo septica (Fig. 9), Hemitrichia serpula (Fig. 10), Physarum album some rather rare ones Dictydiaethalium plumbeum (Fig. 11) and Physarum psittacinum (Fig. 12) were collected namely on $A$. incana. D. plumbeum may be determined as a species with rather limited distribution in Ukraine and Ukrainian Carpathians especially. Fructifications of $D$. plumbeum are known as pseudoaethalia and look like plainly extended on substrate, lead-gray, gray-brown or yellowish-brown crusts with smooth shining or dull surface, in mature pseudoaethalia few right splits are arisen on the surface. At first $D$. plumbeum was collected in Ukraine on the territory of Small (Male) Polissia in vicinity of Lviv $[25,26]$ and three years later it was observed in Carpathian forests near Skole [27]. J. Krupa cited the species under synonymic name Clathroptychium rugulosum (Wallr.) Rostaf. Information about the next record of $D$. plumbeum in Ukraine appeared later 115 years after Krupa's finds. Single specimen of $D$. plumbeum was collected in Mountain Crimea at the territory of Crimea nature reserve in the alder forest along the bank of river Alma [16]. Then D. plumbeum was revealed in Ukraine from some locations on the territories of Left-Bank and Western Polissia, Right- and Left-Bank ForestSteppe etc. $[2-4,8,11,12]$. But in the Ukrainian Carpathians our record of $D$. plumbeum from NNP "Bewitched Land" is the first after Krupa's find in the forests near Skole.

Physarum psittacinum belongs to those members of genus Physarum that cann't be treated as wide-spread in Ukraine and in the world. However, in comparison with D. plumbeum Ph. psittacinum is characterized by the higher frequency of occurrence in Ukraine. The first collection of this species was carried out in Left-Bank Polissia [18]. Further on the additional finds of Ph. psittacinum were made in other locations of the plain part of Ukraine [1, 9, 11, 12, 17, 28]. Mycological observations fulfilled in Ukrainian Carpathians during the last decade showed significant tendency of Ph. psittacinum to develop not only in biotopes of plain territory but in mountain ones too. The locations of Ph. psittacinum are established in Carpathian biosphere reserve, nature reserve

ISSN 1996-4536 • Біологічні Студії / Studia Biologica • 2013 • Том 7/№2 • С. 107-118 

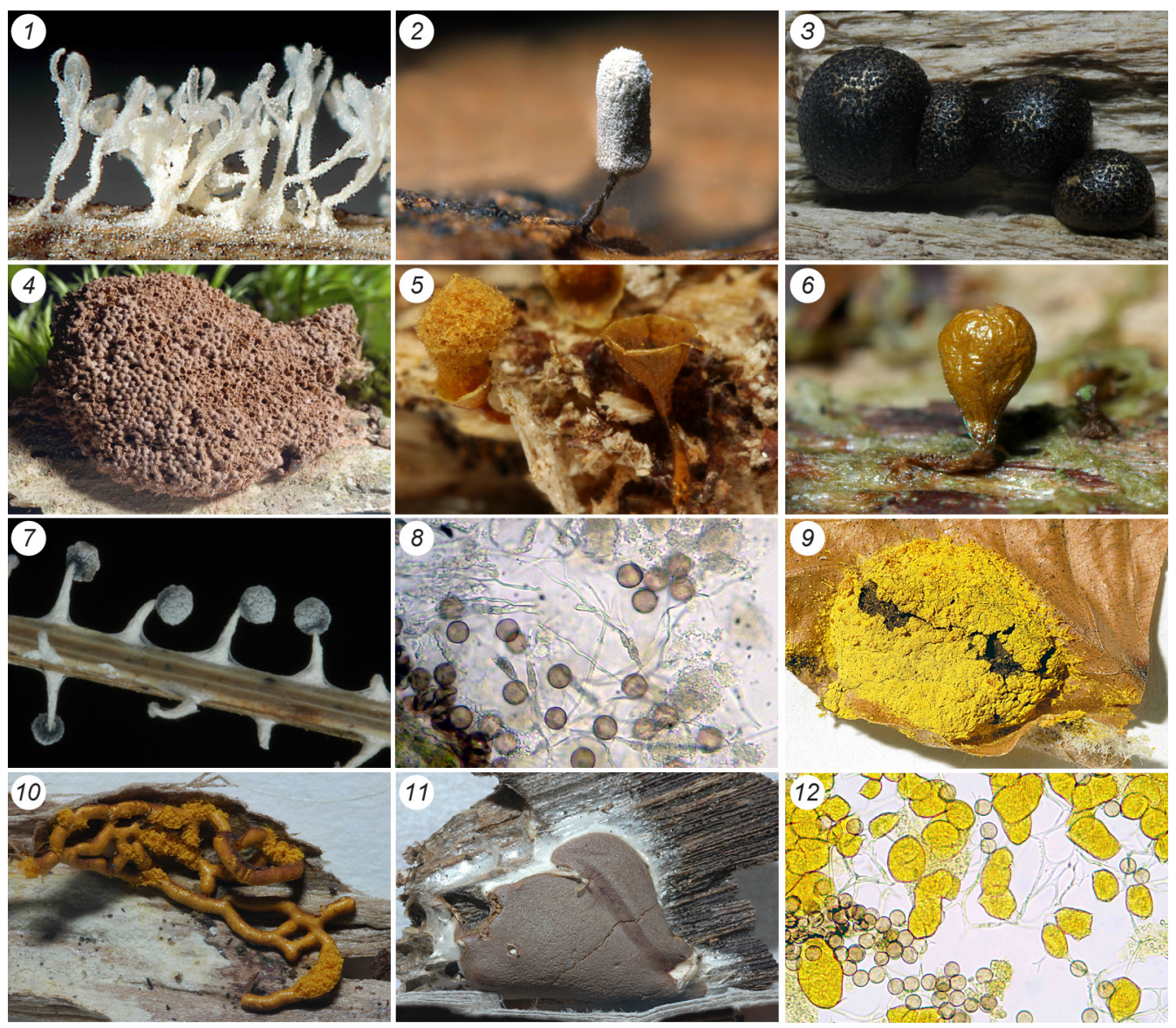

Fig. 1-12: 1 - sporocarps of Ceratiomyxa fruticulosa; 2 - sporocarp of Arcyria cinerea; 3 - aethalies of Lycogala epidendrum; 4 - aethalia of Tubifera ferruginosa; 5 - sporocarps of Hemitrichia calyculata; 6 - sporocarp of Trichia decipiens; 7 - sporocarps of Physarum album; 8 - spores and capillitium of Ph. album; 9 - aethalia of Fuligo septica; 10 - plasmodiocarps of $H$. serpula; 11 - aethalia of Dictydiaethalium plumbeum; 12 - spores and capillitium of Physarum psittacinum

Рис. 1-12: 1 - спорокарпи Ceratiomyха fruticulosa; 2 - спорокарпи Arcyria cinerea; 3 - еталії Lycogala epidendrum; 4 - еталійTubifera ferruginosa; 5 - спорокарпи Hemitrichia calyculata; 6 - спорокарп Trichia decipiens; 7 - спорокарпи Physarum album; 8 - спори і капіліцій Ph. album; 9 еталій Fuligo septica; 10 - плазмодіокарп H. serpula; 11 - еталій Dictydiaethalium plumbeum; 12 - спори і капіліцій Physarum psittacinum

"Gorgany", NNP "Synevyr" [10, 13]. Our find of Ph. psittacinum completed the list of its locations in Ukrainian Carpathians with NNP "Bewitched Land".

Comparison of myxomycete species diversities in NNP "Bewitched Land" and in two other protected nature objects with the virgin beech and the old-aged spruce-fir forests (Carpathian biosphere reserve and NNP "Skolivski Beskydy"), where we studied slime molds earlier [5, 21], showed rather noticeable difference between the species richness of myxomycetes. In NNP "Bewitched Land" 20 myxomycete species were recorded against 18 species in Carpathian biosphere reserve and 27 species in NNP "Skolivski Beskydy". The main reason of such discrepancy between wealth of myxomycete biota in NNP "Bewitched Land" and biosphere reserve, from the one side, and NNP "Skolivski 
Beskydy", from the other side, consists in the different terms for collection of slime molds specimens. It was noted above that mycological inspection of NNP "Bewitched Land" for revealing of myxomycetes was held in summer 2011. The observations on myxomycetes in Carpathian biosphere reserve were predominantly undertaken in spring and summer 2006. Only in NNP "Skolivski Beskydy" autumn 2010 was chosen for collection of these protozoan fungal analogues. The autumn is considered the most suitable time for myxomycete collection as a period when the best correlation between substrate moisture and air temperature is established producing the favorable conditions for slime molds development [35]. Thus the highest level of myxomycete species diversity in NNP "Skolivski Beskydy" is directly connected with the term of its collection.

At the same time, in spite of the difference in quantitative presentation of myxomycetes found at the investigated territories the taxonomic structures of slime molds in three comparable protected nature objects are similar. The family Trichiaceae takes the dominant positions in NNP "Skolivski Beskydy" (15 species from 5 genera) and in Carpathian biosphere reserve ( 7 species and two varieties from 3 genera) the same as in NNP "Bewitched Land" (8 species of 3 genera). The second place in these comparable territories belongs to the family Physaraceae presented in studied national parks with 5 species in each and in biosphere reserve with 4 species. Among the genera Trichia Haller becomes the dominant in "Skolivski Beskydy" (6 species) and biosphere reserve (4 species and two varieties) instead of Arcyria Wigg in "Bewitched Land" (4 species). However, Arcyria yields to Trichia not so much: in "Skolivski Beskydy" Arcyria is presented with 5 species against Trichia with 6 species.

Ecological analysis of myxomycetes consists in the clarification of its substrate distribution that allows to determine relation of certain species to the concrete ecological group. The results on association of myxomycetes from NNP "Bewitched Land" with the different substrate types (Table) support thesis about the wood as a preferable substrate for slime molds in the forest communities. Representatives of xylophilous ecological group prevailed in the myxomycete biota: 18 from 20 recorded species were found on decaying stumps, trunks, logs, fallen branches and twigs of 6 tree's species (Alnus glutinosa (L.) Gaertn., A. incana, Betula pendula Roth, Fagus sylvatica, Malus domestica Borkh and Picea abies) at various stages of decomposition. It should be noted that 3 (Arcyria denudata, Ceratiomyxa fruticulosa, Fuligo septica) from those 18 lignicolous slime molds were marked on bark of trees too. It means they may be considered as members of corticuloid ecological group but in view of their ability at the same time to occupy wood we include them in xylophilous ecological group. Hemitrichia serpula was the single slime mold collected in "Bewitched Land" on the bark only; so this species may be included in corticuloid group. Picea abies and Fagus sylvatica are the two main woody species that were used as a substrate with the greatest numbers of myxomycetes. Alltogether 16 taxa were found on their decaying wood; 13 taxa on the wood of Picea and 8 on the wood of Fagus. It is necessary to attract attention to the numbers of multisubstrate slime molds in NNP "Bewitched Land". Development of fructifications of Arcyria cinerea, A. denudata, Ceratiomyxa fruticulosa, Comatricha nigra, Fuligo septica, Lycogala epidendrum, Physarum album, Ph. viride was observed on 2-3 and even on 5 various substrates. For example, C. fruticulosa was collected on the wood and bark of beech, the wood of spruce and birch and on the basidioma of wood-destroyed fungus; Fuligo septica was found on the wood of living apple tree, the bark of spruce and on living herbal plants. In "Bewitched Land" several species of slime molds (Arcyria affinis, A. incarnata, Stemonitis fusca, S. splendens, Trichia affinis, T. decipiens, Tubifera ferruginosa) were revealed on the wood of

ISSN 1996-4536 • Біологічні Студії / Studia Biologica • 2013 • Том 7/№2 • С. 107-118 


\section{Comparison of species diversity and substrate preferences of myxomycetes from three protected nature objects of the Ukrainian Carpathians}

Порівняння видового різноманіття і субстратних уподобань міксоміцетів із трьох природоохоронних об'єктів Українських Карпат

\begin{tabular}{|c|c|c|c|c|}
\hline \multirow{3}{*}{$\mathrm{Nr}$} & \multirow{3}{*}{ Species } & \multicolumn{3}{|c|}{ Location } \\
\hline & & $\begin{array}{c}\text { National Nature } \\
\text { Park "Bewitched } \\
\text { Land" }\end{array}$ & $\begin{array}{l}\text { Carpathian } \\
\text { Biosphere } \\
\text { Reserve }\end{array}$ & $\begin{array}{c}\text { Natural Nature } \\
\text { Park "Skolivski } \\
\text { Beskydy" }\end{array}$ \\
\hline & & & [21] & [5] \\
\hline 1 & *Arcyria affinis Rostaf. & PAw+ & & FSw+ \\
\hline 2 & ${ }^{*}$ A. cinerea (Bull.) Pers. & $6 \mathrm{FSw}+; \mathrm{PAw}+$ & & AAw+ \\
\hline 3 & ${ }^{*}$ A. denudata (L.) Wettst. & $\mathrm{FSw}+; \mathrm{FSb}+; \mathrm{b}+$ & & $\begin{array}{l}\mathrm{AAw}+; 2 \mathrm{FSw}+ \\
2 \mathrm{FSbw}+\end{array}$ \\
\hline 4 & A. ferruginea Saut. & & & AAw+; PAw+ \\
\hline 5 & ${ }^{*}$ A. incarnata (Pers. ex J.F. Gmel.) Pers. & PAw+ & & FSw+; PTw+ \\
\hline 6 & $\begin{array}{l}\text { *Ceratiomyxa fruticulosa (O.F. Müll.) } \\
\text { T. Macbr. }\end{array}$ & $\begin{array}{l}\mathrm{BPw}+; 3 \mathrm{FSw}+; \\
\mathrm{FSb}+; 2 \mathrm{PAw}+; \mathrm{f}\end{array}$ & FSw+; PAw+ & \\
\hline 7 & $\begin{array}{l}\text { *Comatricha nigra (Pers. ex J.F. Gmel.) } \\
\text { J. Schröt. }\end{array}$ & FSw+; PAw+ & & \\
\hline 8 & Craterium minutum (Leers) Fr. & & $g+$ & I+ \\
\hline 9 & Cribraria aurantiaca Schrad. & & & 3AAw + \\
\hline 10 & C. purpurea Schrad. & & & 3AAw + \\
\hline 11 & Diachea leucopodia (Bull.) Rostaf. & & $\mathrm{FSI+}$ & \\
\hline 12 & $\begin{array}{l}\text { *Dictydiaethalium plumbeum (Schumach.) } \\
\text { Rostaf. }\end{array}$ & Alw+ & & \\
\hline 13 & Didymium difforme (Pers.) Gray & & & $\mathrm{HI}$ \\
\hline 14 & D. squamulosum (Alb. \& Schwein.) Fr. & & & $\mathrm{HI}$ \\
\hline 15 & Fuligo intermedia T. Macbr. & & FSw+ & \\
\hline 16 & $\begin{array}{l}\text { F. leviderma H. Neubert, Nowotny } \\
\text { \& K. Baumann }\end{array}$ & & & FSw+ \\
\hline 17 & ${ }^{\star}$ F. septica (L.) F.H. Wigg. & $\mathrm{MDw}^{*} ; \mathrm{PAb}+; 2 \mathrm{~g}^{*}$ & FSw+ & $\begin{array}{l}\text { 5AAw+; Alw+; } \\
\text { PAw }^{*} ; 2 \text { PAw+ }\end{array}$ \\
\hline 18 & *Hemitrichia calyculata (Speg.) M.L. Farr & FSw+ & & $2 \mathrm{FSw}+$ \\
\hline 19 & H. clavata (Pers.) Rostaf. & & FSw+ & \\
\hline 20 & ${ }^{\star} H$. serpula (Scop.) Rostaf. ex Lister & $\mathrm{Alb}+$ & & $\mathrm{Sb}+$ \\
\hline 21 & Licea minima Fr. & & PAw+ & \\
\hline 22 & *Lycogala epidendrum (L.) Fr. & $\begin{array}{l}\text { AGw+; } 2 \mathrm{FSw}+ \\
\mathrm{PAw}+\end{array}$ & FSw+ & $\begin{array}{l}\mathrm{AAw}+; \mathrm{AGw}+; \\
\mathrm{BPw}+; \mathrm{CBw}+; \\
\text { 4FSw+; PTw+; } \\
\text { Sw+ }\end{array}$ \\
\hline 23 & L. terrestre Fr. & & FSw+ & \\
\hline 24 & $\begin{array}{l}\text { Metatrichia floriformis (Schwein.) } \\
\text { Nann.-Bremek. }\end{array}$ & & FSw+ & \\
\hline
\end{tabular}




\begin{tabular}{|c|c|c|c|c|}
\hline 25 & $\begin{array}{l}\text { M. vesparia (Batsch) Nann.-Bremek. ex } \\
\text { G.W. Martin \& Alexop. }\end{array}$ & & $2 \mathrm{FSw}+$ & $2 \mathrm{AAw}+$ \\
\hline 26 & Perichaena corticalis (Batsch) Rostaf. & & & AGw+ \\
\hline 27 & ${ }^{\text {*Physarum album (Bull.) Chevall. }}$ & 2FSw+; FVg*; ${ }^{+}+$ & & \\
\hline 28 & Ph. cinereum (Batsch) Pers. & & & Sw+ \\
\hline 29 & Ph. leucophaeum Fr. & & & $2 \mathrm{FSw}+$ \\
\hline 30 & ${ }^{*} P h . p s i t t a c i n u m$ Ditmar & Alw+ & & \\
\hline 31 & Ph. robustum (Lister) Nann.-Bremek. & & PAw+ & \\
\hline 32 & *Ph. viride (Bull.) Pers. & FSw+; PAw+ & & \\
\hline 33 & 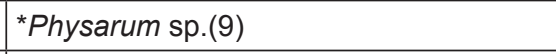 & $g^{*}$ & & \\
\hline 34 & *Stemonitis fusca Roth & PAw+ & & Alw+ \\
\hline 35 & *S. splendens Rostaf. & PAw+ & & \\
\hline 36 & $\begin{array}{l}\text { Stemonitopsis typhina (F.H. Wigg.) } \\
\text { Nann.-Bremek. }\end{array}$ & & FSw+ & \\
\hline 37 & $\begin{array}{l}\text { Symphytocarpus impexus Ing } \\
\text { \& Nann.-Bremek. }\end{array}$ & & & FSw+ \\
\hline 38 & ${ }^{*}$ Trichia affinis de Bary & 2PAw+ & $2 \mathrm{FSw}+$ & \\
\hline 39 & ${ }^{*}$ T. decipiens (Pers.) T. Macbr. & PAw+ & FSw+; PAw+ & 2AAw+; 4FSw+ \\
\hline 40 & T. lutescens (Lister) Lister & & & FSw+ \\
\hline 41 & T. persimilis P. Karst. & & FSw+ & AGw+ \\
\hline 42 & T. scabra Rostaf. & & & $2 \mathrm{AGw}+$ \\
\hline 43 & T. subfusca Rex & & & FSw+ \\
\hline 44 & T. varia (Pers. ex J.F. Gmel.) Pers. & & FSw+; PAw+ & $\begin{array}{l}\text { 3AAw+; } 2 \mathrm{FSw}+ \\
\mathrm{Sw}^{*}\end{array}$ \\
\hline 45 & *Tubifera ferruginosa (Batsch) J.F. Gmel. & 3PAw+ & FSw+ & \\
\hline
\end{tabular}

Legend: $\quad$ AAw+- dead wood of Abies alba; AGw+- dead wood of Alnus glutinosa; Alw+- dead wood of Alnus incana; $\mathrm{BPw}+-$ dead wood of Betula pendula; $\mathrm{CBw}+-$ dead wood of Carpinus betulus; $\mathrm{FSb}+-$ dead bark of $F$. sylvatica; FSbw+ - dead bark and wood of $F$. sylvatica; FSI+ - dead leaves of F. sylvatica; FSw+ - dead wood of Fagus sylvatica; FVg* - stem of living Fragaria vesca; $\mathrm{HI}$ - leaves of Heracleum sp.; MDw* - wood of living tree Malus domestica; PAb+ dead bark of Picea abies; PAw+ - dead wood of P. abies; PAw* - wood of living tree P. abies; PTw+ - dead wood of Populus tremula; Sw+ - dead wood of Salix sp.; Sw* - wood of living tree Salix sp.; $f$ - fruit body of wood-destroyed fungus; $g+-$ dead herbal plants; $g^{*}-$ living herbal plants; I+ - dead tree leaves; $w^{+}+$- dead wood; figure before substrate symbols means the numbers of collected specimens.

Скорочення: AAw+ - мертва деревина Abies alba, AGw+ - мертва деревина Alnus glutinosa, Alw+ мертва деревина Alnus incana, BPw+ - мертва деревина Betula pendula, CBw+- мертва деревина Carpinus betulus, FSb+ - мертва кора Fagus sylvatica, FSbw+ - мертва кора і деревина F. sylvatica, FSI+ - мертві листки F. sylvatica, FSw+ - мертва деревина F. sylvatica, FVg* - стебло живої рослини Fragaria vesca, $\mathrm{HI}$ - листки Heracleum sp., MDw* - деревина живого дерева Malus domestica, PAb+ - мертва кора Picea abies, PAw+ - мертва деревина P. abies, PAw* - деревина живого дерева P. abies, PTw+ - мертва деревина Populus tremula, Sw+ - мертва деревина Salix sp., Sw* - деревина живого дерева Salix sp., f - плодове тіло дереворуйнівного гриба, $\mathrm{g}^{+}-$мертві трав'янисті рослини, $\mathrm{g}^{*}-$ живі трав'янисті рослини, I+ - мертві листки дерев, w+ - мертва деревина; цифри перед символами субстратів відповідають кількості зібраних зразків. 
Picea abies only. However, some of these species were also found on other types of wood outside the study area. It is distinctly shown by our data on myxomycetes of NNP "Skolivski Beskydy" and Carpathian biosphere reserve (Table) where the same species were collected on the wood of beech (Arcyria affinis, Trichia affinis, Tubifera ferruginosa), the wood of beech and aspen (Arcyria incarnata), the wood of speckled alder (Stemonitis fusca), the wood of beech and silver fir (Trichia decipiens). There are many literature data that demonstrate significantly wider range of substrates suitable for colonization with the mentioned myxomycete species [20,36].

More limited woody substrates than the beech and spruce ones are presented in NNP "Bewitched Land" by the speckled alder (Alnus incana), areal of which in Ukraine is connected with Carpathian region. Only three myxomycete species were found on the substrates produced by $A$. incana. Dictydiaethalium plumbeum and Physarum psittacinum are associated with the wood and Hemitrichia serpula - with the bark of speckled alder. It should be noted the first record of $D$. plumbeum in Ukraine was made in XIX century at the same substrate: stumps of $A$. incana [26]. But narrow adaptation of this species to $A$. incana is doubtful: at the same time with the finds on speckled alder wood D. plumbeum was collected on the wood of black alder (Alnus glutinosa) [26]. Later the list of $D$. plumbeum substrates enlarged: it was revealed on bark and wood of Betula pendula, wood of Fraxinus excelsior L., Carpinus betulus L. and Quercus robur L., wood of unidentified tree $[2,4,11,12,16]$. The numbers of substrates on which Ph. psittacinum fructifications were observed in Ukraine are much more numerous and include not only the bark, wood and leaf litter of deciduous trees (lime, oak, aspen, hornbeam) [9, $11,12]$ but the wood of coniferous ones (spruce and fir), mosses, fruit bodies of wooddestroyed fungi too $[1,10,13]$.

\section{CONCLUSION}

Ecological analysis of myxomycete substrate preferences showed that the most important woody species that supported the development of the majority of slime molds in NNP "Bewitched Land" were spruce (Picea abies) and beech (Fagus sylvatica). At previous studies of myxomycetes in the forest communities of Ukrainian Carpathians [5, 10, $13,21]$ it was established that usually myxomycetes occurred, first of all, on dead wood of deciduous trees; coniferous wood is used as a substrate with a smaller number of the specialized slime molds. As an example of such association with the wood of deciduous trees myxomycetes of Carpathian biosphere reserve that clearly demonstrate preference in relation of the beech wood are given in Table. Myxomycete biota of "Bewitched Land" shows reverse type of substrate association using as preferable the wood of coniferous tree-spruce. Possibly prevail of slime molds on the wood of spruce in the study area may be connected with the stage of its decomposition which was more suitable for myxomycete development than the stage of beech wood destruction. The slime molds which develop in NNP "Bewitched Land" only on such limited substrate as the speckled alder wood are known as colonizers of the different woody substrates in various regions of Ukraine.

\section{ACKNOLEGEMENTS}

The authors thank the Head of National Nature Park "Bewitched Land" V.I. Radik for help in organizing of expedition work and the assistant professor of Uzhgorod National University L.M. Fel'baba-Klushina for participation in joint expedition to the swamp "Black Bog". 
1. Дудка И.А., Кривомаз Т.И. Миксомицеты Ичнянского национального природного парка Украины. Микология и фитопатология, 2008; 42(5): 423-439.

2. Дудка I.О., Кривомаз T.I. Міксоміцети Деснянсько-Старогутського національного природного парку. Наук. вісник Чернів. нац. ун-ту. Біологія, 2005; 260: 111-117.

3. Дудка І.О., Кривомаз T.І. Міксоміцети як компонент біологічного різноманіття Національного природного парку „Святі гори”. Екол. вісник, 2006; 5(39): 4-6.

4. Дудка І.О., Кривомаз Т.І. Літній аспект біоти міксоміцетів національного природного парку „Прип'ять-Стохід”. Чорномор. ботан. журнал, 2011; 7(1): 67-83.

5. Дудка І.О., Кривомаз Т.І., Аніщенко І.М. Національний природний парк „Сколівські Бескиди" - полігон для довготривалого моніторингу змін таксономічного різноманіття міксоміцетів. У кн.: Роль природоохоронних установ у збереженні біорізноманіття, етнокультурної спадщини та збалансованому розвитку територій: матер. наук.-практ. конф. (м. Косів, 18-19 травня 2012 р.). Косів, 2012: 130-134.

6. Зелена книга України / під заг. ред. чл.-кор. НАН України Я.П. Дідуха. Київ: Альтерпрес, 2009. 448 c.

7. Кривомаз Т.І. Таксономічна структура та особливості екології міксоміцетів лісів України: автореф. дис....канд. біол. наук: спец. 03.00.21 „Мікологія”. Київ, 2010. 29 с.

8. Леонтьев Д.В. Новые находки миксомицетов из Каневского природного заповедника. В кн.: Актуальні проблеми біології в дослідженнях молодих учених Харківського університету: матер. конф. (м. Харків, 11-13 листопада 2003 р.). Харків, 2003: 17-19.

9. Леонтьєв Д.В. Міксоміцети національного природного парку „Гомільшанські ліси”: автореф. дис....канд. біол. наук: спец. 03.00.21 „Мікологія”. Київ, 2007. 20 с.

10. Леонтьєв Д.В., Дудка І.О., Кочергіна А.В. та ін. Міксоміцети національного природного парку „Синевир”. Укр. ботан. журнал, 2010; 67 (4): 615-622.

11. Леонтьєв Д.В., Дудка І.О., Кривомаз Т.І. До біоти міксоміцетів національного природного парку „Подільські Товтри”. В кн..: Біологія: від молекули до біосфери. Матер. III Міжнар. конф. молодих учених м. Харків, 18-21 листопада 2008 р. Харків, 2008: 416-417.

12. Леонтьєв Д.В., Дудка І.О., Кривомаз Т.І. Міксоміцети (Myхоmусеtes) національного природного парку „Подільські Товтри”. Укр. ботан. журнал, 2009; 66(2): 240-249.

13. Леонтьєв Д.В., Дудка І.О., Маланюк В.Б. та ін. Міксоміцети природного заповідника „Горгани”. Укр. ботан. журнал, 2013; 70(1): 94-102.

14. Мигаль А.В., Андрик Є.Й., Кіш Р.Я. та ін. Зачарований край. В кн.: Фіторізноманіття заповідників і національних природних парків України. Ч.2. Національні природні парки / під ред. к.б.н., с.н.с. В.А. Оніщенка і д.б.н., профр. Т.Л. Андрієнко. Київ: Фітосоціоцентр, 2012. С. 250-256.

15. Новожилов Ю.К. Определитель грибов России: отдел Слизевики. Вып. 1. Класс Миксомицеты. СПб.: Наука, 1993. 288 с.

16 Романенко К.О. Видове різноманіття міксоміцетів Кримського природного заповідника. Заповідна справа в Україні, 2001; 7(1): 26-32.

17 Целле М.О. Матеріяли до фрлори міксоміцетів України. Вісник Київ. ботан. саду, 1925; 2: 31-39.

18. Borščow I.G. Ein Beitrag zur Pilzflora der Provinz Chernigoff. Bull. Acad. Sci. St.-Petersb, 1868; 13: 219-245.

19. Commarmot B., Bachofen H., Bundziak Y. et al. Structures of virgin and managed beech forests in Uholka (Ukraine) and Sihlwald (Switzerland): a comparative study. For. Snow Landsc. Res, 2005; 79: 45-56.

20. Drozdowicz A., Szolc P., Bochynek A. et al. Myxomycetes of the Lipówka reserve in the Niepolomice old growth forest (S Poland). Acta Mycol, 2012; 47(1): 97-107.

21. Dudka I.O., Leontyev D.V. Myxomycetes in virgin forests of Carpathian biosphere reserve. Біол. студії, 2011; 5(1): 45-56.

22. Ing B. The Myxomycetes of Britain and Ireland. An Identification Handbook. Slough: The Richmond Publishing Co. Ltd., 1999. 374 p.

23. Kirk P.M., Ansell A.E. Authors of Fungal Names. A list of authors of scientific names of fungi, with recommended standard forms of their names, including abbreviations. Wallingford: CAB International, 1992. $95 \mathrm{p}$.

ISSN 1996-4536 • Біологічні Студії / Studia Biologica • 2013 • Том 7/№2 • С. 107-118 
24. Kirk P.M., Cannon P.F., David J.C. et al. Ainsworth \& Bisby's Dictionary of the Fungi. $10^{\text {th }}$ ed. Wallingford: CAB International, 2008. $771 \mathrm{p}$.

25. Krupa J. Zapiski mycologiczne przeważnie z okolic Lwowa i z Tatr. Kosmos, 1886; 11: 370399.

26. Krupa J. Zapiski mycologiczne z okolic Lwowa I z Podtatrza. Sprav. Kom. Fizyogr, 1888; 22(2): 12-47.

27. Krupa J. Zapiski mycologiczne z okolic Lwowa I z Karpat stryjskich. Sprav. Kom. Fizyogr, 1889; 23(1): 141-169.

28. Krzeminiewska $H$. Śluzowce zebrane w starym ogrodzie botanicznym we Lwowie. Kosmos, 1937; 62: 17-26.

29. Lado K. Novenmyx. A nomenclatural taxabase of Myxomycetes. Madrid: Cuadenos deTrabajo de Flora Micologica Iberica, 2001. 224 p.

30. Lister A. A Monograph of the Mycetozoa. London: British Museum, 1925. $296 \mathrm{p}$.

31. Martin G.W., Alexopoulus C.V. The Myxomycetes. lova City: lowa Univ. Press, 1969. 560 p.

32. Mosyakin S.L., Fedoronchuk M.M. Vascular Plants of Ukraine. A Nomenclatural Checklist. Kiev, 1999. 345 p.

33. Nannenga-Bremekamp N.E. A Guide to Temperate Myxomycota. Bristol: Biopress Ltd., 1991. 410 p.

34. Poulain M., Meyer M., Bozonnet J. Les Myxomycètes. Vol. 2. Dauphiné-Savoie: Sarl Edition, 2011. $1119 \mathrm{p}$.

35. Stephenson S.L., Stempen H. Myxomycetes: A Handbook of Slime Molds. Portland, Oregon: Timber Press, 1994. 183 p.

36. Stojanowska W., Panek E. Myxomycetes of the nature reserve near Walbrzych (SW Poland). Part II. Dependence on the substrate and seasonality. Acta Mycol, 2004; 39(2): 147-159.

37. http://www.panda.org/europe/forests

\title{
МІКСОМІЦЕТИ БУКОВИХ ПРАЛІСІВ І СТАРОВІКОВИХ ЯЛИНОВИХ ЛІСІВ НАЦІОНАЛЬНОГО ПРИРОДНОГО ПАРКУ „ЗАЧАРОВАНИЙ КРАЙ” (УКРАЇНСЬКІ КАРПАТИ)
}

\author{
I. О. Дудка', Т. І. Кривомаз \\ ${ }^{1}$ Інститут ботаніки ім. М. Г. Холодного НАН України \\ вул. Терещенківська, 2, Київ 01601, Україна \\ e-mail: i_dudka@mail.ru \\ ${ }^{2}$ Київський національний університет будівництва і архітектури \\ Повітрофрлотський просп.,31, Київ 03680, Україна
}

Мікологічні спостереження, проведені у липні 2011 р. у букових пралісах і старовікових ялинових лісах Національного природного парку (далі НПП) „Зачарований край”, дали змогу виявити 20 видів міксоміцетів. Ceratiomyхa fruticulosa - єдиний вид, що належить до підкласу Ceratiomyхоmycetidae, інші 19 видів є представниками підкласу Myхogastromycetidae, у складі якого розподіляються за чотирма порядками: Trichiales (8 видів), Physarales (5), Liceales та Stemonitales (по 3 види в кожному). Найбільшою частотою трапляння відзначаються Ceratiomyхa fruticulosa, Arcyria cinerea та Lycogala epidendrum. Dictydiaethalium plumbeum є видом із доволі обмеженим поширенням в Україні і особливо в Українських Карпатах. Вивчення субстратних уподобань міксоміцетів показало, що найбільш важливими деревними породами, які утворюють субстрати для розвитку більшості міксоміцетів у НПП "Зачарований край”, є ялина (Picea abies) та бук (Fagus sylvatica). На відміну від Карпатського біосферного заповідника та НПП „Сколівські Бескиди”, де міксоміцети переважно 
використовують як субстрат деревину бука, біота міксоміцетів НПП „Зачарований край" продемонструвала зворотний тип асоціації зі субстратом, надавши перевагу деревині шпилькової породи - ялини.

Ключові слова: Національний природний парк „Зачарований край”, Мухотуcetes, слизовики, праліси та старовікові ліси, таксономічне різноманіття, субстратні уподобання.

\title{
МИКСОМИЦЕТЫ КОРЕННЫХ БУКОВЫХ И СТАРОВОЗРАСТНЫХ ЕЛОВЫХ ЛЕСОВ НАЦИОНАЛЬНОГО ПРИРОДНОГО ПАРКА «ЗАЧАРОВАННЫЙ КРАЙ» (УКРАИНСКИЕ КАРПАТЫ)
}

\author{
И. А. Дудка', Т. И. Кривомаз 2 \\ ${ }^{1}$ Институт ботаники им. Н.Г. Холодного НАН Украины \\ ул. Терещенковская, 2, Киев 01601, Украина \\ e-mail: i_dudka@mail.ru \\ ${ }^{2}$ Киевский национальный университет строительства и архитектуры \\ Воздухофрлотский просп., 31, Киев 03680, Украина
}

Микологические наблюдения, проведенные в июле 2011 г. в коренных буковых и старовозрастных еловых лесах Национального природного парка (далее НПП) “Зачарованный край”, позволили обнаружить 20 видов миксомицетов. Ceratiomyха fruticulosa - единственный вид, относящийся к подклассу Ceratiomyхотycetidae, остальные 19 видов являются представителями подкласса Myxogastromycetidae, в составе которого распределены между четырьмя порядками: Trichiales (8 видов), Physarales (5), Liceales и Stemonitales (по 3 вида в каждом). Наибольшей частотой встречаемости характеризуются Ceratiomyха fruticulosa, Arcyria cinerea и Lycogala epidendrum. Dictydiaethalium plumbeum является видом с довольно ограниченным распространением в Украине и особенно в Украинских Карпатах. Изучение субстратных предпочтений миксомицетов показало, что чаще других древесных пород в НПП „Зачарованный край” обеспечивают развитие миксомицетов субстраты из ели (Picea abies) и бука (Fagus sylvatica). В отличие от Карпатского биосферного заповедника и НПП „Сколевские Бескиды”, где миксомицеты преимущественно используют как субстрат древесину бука, биота миксомицетов НПП „Зачарованный край” продемонстрировала обратный тип ассоциации с субстратом, отдавая предпочтение древесине хвойной породы - ели.

Ключевые слова: Национальный природный парк „Зачарованный край”, Myxomycetes, слизевики, коренные и старовозрастные леса, таксономическое разнообразие, субстратные предпочтения.

Одержано: 15.04.2013

ISSN 1996-4536 • Біологічні Студії / Studia Biologica • 2013 • Том 7/№2 • C. 107-118 